\title{
PERTANGGUNGJAWABAN PRESIDEN \\ DAN HUBUNGANNYA DENGAN MAHKAMAH KONSTITUSI \\ MENURUT AMANDEMEN UUD 1945
}

Oleh:

Noor Trihastuti

\begin{abstract}
Power And responsibility of President of Republic Of Indonesia by normatif it is true have experienced of the friction from pattern of system of quasi presidensial before amandemen UUD 1945 to pure system presidensial pattern hereafter amandemen UUD 1945. However, by yuridis is constitutional, second of the pattern hitherto still be executed difficult purely and konsekuen, because of various factor, for example: its his weak 1 domicile and kewenangan institute the State in charge to ask the President responsibility strength is political party importance influence in cabinet compilation. As a result, system of President responsibility in Body Politic Indonesia can be told still stay in the vacuous column.
\end{abstract}

Keyword : Power, President Responsibility, Authoritative Institute The State In Charge To Ask The President Responsibility

A. ORIENTASI PEMBATASAN KEKUASAAN NEGARA

\section{Esensi Konstitusiolalisme}

Faktor pendorong munculnya gagasan tentang pembatasan kekuasaan negara adalah karena sifat kekuasaan memang cenderung untuk dikorup atau disalahgunakan oleh pemegangnya. Lord Acton dengan tegas menyatakan bahwa: "Power tends to corrupt, and absolute power corrupts absolutely". Kenyataan ini, tidak hanya terjadi di zaman kerajaan- kerajaan absolut tanpa konstitusi, tetapi juga dapat terjadi di negara-negara Kerajaan Konstitusional den Republik Konstitusional di masa sekarang. Apalagi, jika norma-norma konstitusi suatu negara sangat longgar sehingga membuka ruang yang lebar bagi pemegang kekuasaan untuk menginterpretasikannya sesuai sclera atau kemauan para penguasa.

Karena itu, salah satu cara untuk mengatur den membatasi kekuasaan itu adalah, lewat konstitusi. Make konstitusi menurut No D. Duchacek merupakan, "identify the sources, purposes, uses, and 
restraints of public power (Ivo. D. Duchacek, 1987 : 142). Di mana, pembatasan kekuasaan pada umumnya dianggap merupakan corak umum materi konstitusi. Persis di titik ini, konstitusionalisme, kata Friedrich, merupakan "an institutionalised system of effective, regularised restraints upon governmental action. (C.]. Friedrich, $1963: 217$ ).

Berdasarkan catatan sejarah klasik, gagasan tentang pembatasan kekuasaan negara sebenamya sudah muncul dalam kebudayaan Yunani Kuno lewat apa yang disebut politeia.(Jimly Asshiddiqie, 2004 : 1). Menurut Charles $\mathrm{H}$. Mclllwain, istilah constitution yang muncul di jaman kekuasaan Romawi, digunakan sebagai istilah teknis untuk menyebut the acts of legislation by the Emperor.(Charles H, 1966 : 23)

Di Inggris, peraturan yang pertama kali menggunakan term konstitusi ialah Constitution of Clarendon 1164. Oleh Raja Henry II, peraturan ini disebut sebagai constitutions atau avitae constitutions. Isi peraturan tersebut masih bersifat eklesiastik, rneski pada masamasa berikutnya term constitutio itu sering dipertukarkan satu sama lain dengan lex atau edictum yang menunjuk pada secular administrative enactments. (Jimly Asshidiqie, 2004 : 2). Dalam konteks ini, Glanvill sering menggunakan term constitution untuk titah raja (a royal edict).

Masih di Inggris, bagian tertentu dari Undang-undang Merton tahun 1236 dan Magna Charta, disebut oleh Bracton sebagai a new constitution untuk UU Merton, dan constitutio libertatis untuk Magna Charta.( Jimly Asshidiqie, 2004, hlm.3). Sejak itu untuk waktu berabadabad kemudian, term constitution selalu dimaknai sebagai a particular adminstrative enactment much as it had meant to the Roman lawyers. Term constitution ini dipakai untuk membedakan antara a particular enactment dari consuetudo ataupun ancient custom. Jadi bisa dikatakan bahwa hakikat term constitution di saat itu, menunjuk pada apa yang diungkap oleh Sir James Whitelocke, the natural frame and constitution of the policy of this Kingdom, which is jus publicum regni.

Dua konsepsi konsepsi konstitusi berawal dari ungkapan Whitelocke itu. Pertama, konstitusi sebagai the natural frame of the state yang sejajar dengan politeia dalam konsep Yunani. Kedua, konstitusi dalam arti jus publicum regni 
yang bermakna the public law of the realm.

Di lingkungan Kerajaan Romawi, term constitutio juga dipakai sebagai istilah teknis untuk menyebut the acts of legislation by the Emperor. Dapat dimengerti, orang yang dapat dianggap pertama menggunakan term constitutio dalam arti konsepsi jus publicum regni adalah Cicero.(R.N Berki, 1988 : 74). Menurut Cicero, "this constitution has a great measure of equability without which men can hardly remain free any length of time (Jimly Asshidiqie, 2004 : 4).

Kesehmihan perkembangan itulah yang pada gilirannya menghantarkan perumusan constitution itu sebagai the make or composition which determines the nature of anything, dan dalam pengertian yang demikian, konstitusi selalu dianggap sebagai regulasi yang mengatasi pemerintahan dan segala keputusan serta peraturan lainnya.

Upaya mewujudkan menurut historisnya, pembatasan kekuasaan negara juga berkembang di Eropa abad ke-16 dan ke-17. Terutama, ketika negara-negara bangsa (nation states) mendapatkan bentuknya yang sangat kuat, sentralistis, dan sangat berkuasa selama abad-abad itu, terjadi pula praktik otoritarianisme yang sangat keji. Pengalaman itu memicu munculnya perlawanan untuk mengakhiri kekejian tersebut. Inilah embrio kemunculan gagasan perlindungan hak-hak dasar rakyat yang kemudian terkristal dalam apa yang dikenal sekarang dengan konstitusi dan konstitusionalisme.

Oleh karena itu, konstitusionalisme di zaman sekarang dianggap sebagai suatu konsep yang niscaya bagi setiap negara modem yang berporos pada hak asasi, demokrasi, dan rule of law. Basis pokoknya adalah kemenangan rakyat yang dipelopori kaum borjuis untuk menjatuhkan sistem standestaat yang berlaku zaman itu. Dengan begitu, kesepakatan dan persetujuan umum antara mayoritas rakyat, menjadi basis format negara ideal, negara hukum yang demokratis.

Organisasi negara yang demikian itu diperlukan oleh rakyat agar kepentingan mereka bersama dapat dilindungi dan dipromosikan melalui pembentukan dan penggunaan mekanisme yang disebut konstitusi dalam semangat kons- 
titusionalisme.(William G. Andrew, 1968 :9)

Menurut Andrew, konsensus yang menjamin tegaknya konstitusionalisme di zaman modem pada umumnya dipahami bersandar pada tiga elemen kesepakatan.( William G. Andrew, 1968 :1213) Pertama, kesepakatan mengenai tujuan dan cita-cita bersama. Kesepakatan ini sangat menentukan tegaknya konstitusi dan konstitusionalisme di suatu negara, karena cita-cita bersama itulah yang pada puncaknya paling mungkin mencerminkan kesamaan kesamaan kepentingan di antara sesama warga dengan pluralistas dan heterogenitasnya. Kedua, kesepakatan tentang the rule of law sebagai landasan pemerintahan atau penyelenggaraan negara. Kesepakatan ini juga amat penting karena dalam suatu negara haras ada keyakinan bersama bahwa apapun yang hendak dilakukan dalam konteks penyelenggaraan negara, haruslah didasarkan pada supremasi hukum, bukan menurut maunya orang kuat.

Di Amerika Serikat, doktrin ini dikembangkan menjadi semboyan yang monumental dan seminal, "the rule of law, and not of Man". Semboyan ini untuk menggambarkan bahwa hukumlah yang sesungguhnya memerintah dalam suatu negara, bukan kehendak manusia. Ketiga, kesepakatan tentang bentuk institusi-institusi dan prosedur ketatanegaraan.

Kesepakatan ini berkenaan dengan (a). Bangunan organ negara dan prosedur yang mengatur kekuasaannya, (b). Hubungan-hubungan antar organ itu satu sama lain, (c). Hubungan organ negara dengan warga negara.

Dengan adanya kesepakatan itu, maka isi konstitusi dapat dengan mudah dirumuskan karena benar-benar mencerminkan keinginan bersama berkenaan dengan institusi negara dan mekanisme ketatanegaraan yang demokratis. Sekalian kesepakatan dalam tiga kategori itu pula yang dirumuskan dalam dokumen konstitusi yang diharapkan jadi pegangan bersama untuk kepentingan semua.

Inti semua itu adalah limited government yang merupakan core conception dari konstitusionalisme. Karena itu, menurut Andrews, "under constitutionalism, two types of limitations impinge on government power proscribe and procedures prescribed" (William G. 
Andrew, 1968:13) kekuasaan dilarang dan prosedur ditentukan. Kiranya jelas, fungsi konstitusionalisme mencakup paling sedikit tiga hal, seperti diungkapkan Andrews: (1). Menentukan pembatasan terhadap kekuasaan, (2). Memberi legitimasi pada kekuasaan pernerintahan (yang berbasis rule of law), (3). Sebagai instrumen untuk mengalihkan kewenangan dari constituent power kepada organ kekuasaan negara.( William G. Andrew, 1968 : 23)

Sebuah konstitusi, kata Thomas Paine, is not the act of a government but of the people constituting a government" .(Chareles H. Mcllwain, 1966, him. 20). Konstatasi ini diperkuat oleh Mcllwain, bahwa secara tradisional, sebelum abad ke-18, konstitusionalisme selalu dilihat sebagai a set of principles embodied in the institutions of a nation yang superior, tidak ada kekuatan lain yang mengatasinya.( Chareles H. Mcllwain, 1966 :12)

Bagi Brian Thomson, konstitusi merupakan "a document which contains the rules for the operation of an organization" (Brian Thompson, 1997: 3). Konsep Thomson ini, mungkin melahirkan pemahaman bahwa konstitusi selalu merupakan dokumen tertulis. Dalam dunia modern, konstitusi tidak hanya menunjuk pada dokumen tertulis, tapi juga termasuk praktik-praktik ketatanegaraan. Ini tercermin dalam konsep yang dikemukakan oleh Phillips Hood dan Jackson, bahwa konstitusi merupakan "a body of law, customs and conventions that define the composition and powers of the organ of the States and that regulate the relations of the various State organs to noe another and to the private citizen. Phillips O. Hood \& Jackson, $1987: 5$ )

Meski menjadi konsep yang sudah diterima umum tentang konstitusi, konsep Hood itu sebenarnya menunjuk pada konstitusi Inggris sebagai sebuah negara seperti juga Israel yang tidak mengenal naskah tertulis yang disebut UndangUndang Dasar. Memang sebagaimana diketahui, konstitusi Inggris merupakan bangunan prinsip kenegara-an yang terdiri dari aturan, adat istiadat, kebiasaankebiasaan yang menentukan susunan dan kekuasaan organ-organ negara, serta yang mengatur hubungan antara berbagai organ itu, dan hubungan organ-organ negara itu dengan warga negara.

Pengaturan mengenai pengawasan dan pembatasan kekuasaan pe- 
merintah merupakan persoalan yang amat sentral dalam setiap konstitusi.

Dalam konstitusi harus ada sistern yang terlembagakan menyangkut pembatasan yang efektif dan teratur terhadap penyelenggaraan kekuasaan dalam negara.

Tentu saja legitimasi sebuah konstitusi sebagai hukum dasar yang mengikat, ditentukan oleh prinsip kedaulatan yang dianut sebuah negara. Jika negara itu menganut kedaulatan rakyat, maka sumber legitimasi konstitusi itu sudah tentu adalah rakyat. Jika yang dianut adalah faham kedaulatan raja, maka raja yang menentukan berlaku tidaknya konstitusi tersebut. Penentu legitimasi (entah rakyat, raja, atau yang lainnya) itulah yang oleh para ahli disebut sebagai constituent power.(Brian Thompson, $1997: 5$ )

Berkaitan dengan konsep constituent power tersebut, muncul pula konsep constituent act. Dalam hal ini, konstitusi dianggap sebagai constituent act itu. la bukan produk legislasi yang biasa (ordinary legislative act), la merupakan aturan yang superior yang berasal dari sang pemilik kedaulatan, yakni constituent power. Kata J Bryce demikian.

"...is embodied proceeds from a source different from that whence spring other laws, is regulated in a different way, and exerts a sovereign force. It is enacted not by the ordinary legislative authority but by some higher and specially empowered body. When any of its p'.ovisions conflict with the provisions of the ordinary law, it prevails and the ordinary law must give way"(J Bryce, 1901: 151)

Sudah tentu konstatasi Bryce itu menunjuk pada konstitusi tertulis yang mensyaratkan adanya cara dan prosedur pembuatan serta lembaga dengan otoritas khusus untuk membuatnya. Karena constituent act itu legitimasinya bersumber dari pemilik kedaulatan, yaitu constituent power, maka constituent act itu juga menjadi pusat hirakhi hukum.

Dengan kata lain, konstitusi merupakan hukum yang lebih tinggi atau bahkan paling tinggi serta paling fundamental sifatnya yang menjadi titik tolak dan batu uji semua produk hukum di bawahnya. Sesuai prinsip hukum yang berlaku universal (prinsip stufenbau), agar peraturan perundangan yang tingkatannya berada di bawah konstitusi (UUD) punya justifikasi untuk berlaku dan diberlakukan, 
maka sekalian peraturan itu tidak boleh bertentangan dengan hukum yang lebih tinggi tersebut.

Sebagai "politico-legal document" (dokumen hukum dan politik) nasional yang utama, konstitusi sekaligus berfungsi sebagai dokumen identitas sebuah negara. Sebab, konstitusi sesungguhnya berstatus sebagai sumber dan dasar cita bangsa dan negara yang berupa nilai-nilai dan kaidah-kaidah dasar bagi kehidupan bernegara. Konstitusi memuat cita-cita rakyatnya, di samping asas-asas ideologi negara. la mencerminkan semangat dan spirit berbangsa, bernegara, dan bermasyarakat bagi rakyatnya. Jelaslah, bahwa sebagai hukum dasar, suatu konstitusi selain mengatur organisasi negara dan struktur pemerintahan, juga memuat rechsidee dan cita-cita negara.

\section{Konsep Negara Hukum}

Terdapat ragam konsep negara hukum yang dikemukakan oleh para pakar hukum terkemuka, anatara lain:

a. Berawal dari pemikiran Immanuel Kant tentang negara hukum dalam arti sempit (rechtsstaat in enge zin) yang menempatkan fungsi rechts pada staat hanya sebagai alat perlindungan hakhak asasi individual dan pengaturan kekuasaan negara secara pasif, yakni hanya bertugas sebagai pemelihara ketertiban dan keamanan masyarakat. (Azhary, 1995 : 66). Dalam perkembangan negaranegara modem abad ke-19, konsep Kant tersebut dinilai kurang memuaskan, maka berkembanglah kemudian konsep yang lebih luas tentang rechtsstaat yang berwawasan w e I v a a r s $t$ a a $t \mathrm{~d}$ a $\mathrm{n}$ verzorgingsstaat atau berwawasan kesejahteraan dan kemakmuran. Unsur-unsur utama rechtsstaat yang berwawasan demikian itu, dielaborasi oleh sejumlah ahli dengan berbagai varian. Ada yang menekankan unsur-unsur pengakuan dan perlindungan hak-hak asasi manusia, pemisahan kekuasaan negara menurut prinsip Trias Politica, wetmatig bestuur, dan peradilan 
administrasi negara-seperti diajukan oleh Stah. Ada pula yang menekankan unsur-unsur kepastian hukum, persamaan, demokrasi, dan pemerintahan yang melayani kepentingan umum seperti diajukan Sheltema.

b. Van Wijk dan Konijnenbelt memberi perhatian pada unsurunsur pemerintahan berdasarkan hukum, hak-hak asasi, pembagian kekuasaan, dan pengawasan oleh kekuasaan peradilan. (A. Hamid Atamimi, 1990 : 311). Sedangkan Zippelius memberi penekanan pada unsurunsur pemerintahan menurut hukum, jaminan ter-hadap hakhak asasi, pembagian kekuasaan, dan pengawasan yustisial terhadap pemerintah. Pada negaranegara Anglo Saxon, umumnya pemahaman terhadap negara hukum mengikuti konsep "Rule of Law"dariA.V.

C. Dicey dengan unsur-unsur utama supremacy of law, equality before the law, and the constitution based on individual rights.(5J. Von Schmid : 248). Pada prinsipnya, antara konsep "Rule of Law" dan

"RechtsstaaF memiliki persamaan, terutama soal landasan filosofi yang berbasis liberalistik-individual, pembatasan kekuasaan negara berbasis wetmatig, serta pemisahan secara mutlak antara negara dan agama. d. Lebih lanjut, F.J. Stahl merumuskan, bahwa negara hukum modem harus memenuhi minimal empat syarat, yakni :(1) Negara harus melindungi hak-hak asasi manusia, (2) Harus ada pemisahan dan pembagian kekuasaan, (3) Pemerintahan harus berdasarkan hukum, (4) Harus ada peradilan administrasi. (S.F Marbun, 1997, him. 9) e. Paul Scholten, menyebut ada tiga unsur utama negara hukum, yakni: (1) Diakuinya hak-hak asasi manusia, (2) Adanya pemisahan kekuasaan, (3) Adanya pemerintahan yang berdasarkan undang-undang.

d. Sedangkan Sri Soemantri menyebut empat unsur negara hukum; (1) Pemerintah dalam melaksanakan tugas dan 
kewajibannya harus berdasarkan hukum atau peraturan perundangan, (2) Adanya jaminan hak asasi manusia (warga negara), (3) Adanya Pembagian kekuasaan dalam negara, (4) Adanya pengawasan dad badan peradilan (rechteriijke controle). (Sri Sumantri, 1992: 10)

Dapatlah dikatakan bahwa supremasi hukum, jaminan hak-hak asasi manusia, check and balances dalam negara, dan rechteriijke controle, menjadi ikon negara modem sebagai negara hukum yang demokratis. Sistem konstitusi yang menjadi salah satu gagasan normatif negara hukum, membawa konsekuensi bahwa harus mengikuti empat prinsip imperatif konstitusionalisme, yaitu: (1). Seluruh kekuasaan politik harus tunduk pada hukum. (2). Adanya jaminan dan perlindungan hak-hak asasi manusia. (3). Peradilan yang bebas dan mandiri, (4). Akuntabilitas publik, sebagai sendi utama kedaulatan rakyat.

Supremasi hukum, merupakan ide normatif untuk mencegah atau menghindari teradinya kesewenangwenangan dan terjaminnya equality before the law. (M.Mahfud MD, 2000 :10). Selain itu, ide "negara berdasarkan hukum", memunculkan keharusan imperatif agar seluruh kekuasaan politik mesti tunduk pada hukum.

Perlindungan hak-hak asasi manusia, merupakan ide normatif untuk menjamin hak-hak rakyat sebagai pihak yang diperintah.(C.F Strong, 1966 : 1). Checks and balances merupakan ide normatif untuk menghindari terjadinya absolutisme dalam pelaksanaan kekuasaan negara dan untuk menjamin berjalannya demokrasi. Sedangkan rechterlijke controle (Sri Soemantri, 1992 : 10) merupakan ide normatif untuk menghindari terjadinya pemaksaan kehendak oleh pihak yang kuat terhadap yang lemah, termasuk antara yang memerintah dan yang diperintah.

Jelas, betapa core conception tentang negara hukum, tidak saja dimaksudkan untuk menjamin sistem bernegara yang demokratis (berkedaulatan rakyat), tetapi juga mencegah terjadinya kekuasaan yang tanpa batas yang potensil bagi penidasan dan penyalahgunaan kekuasaan. Untuk masa kini, konsep Negara modem, identik dengan negara hukum yang demokratis. 
(Arief Budiman, 1966: 23) Di situ, ada pemisahan atau pembagian kekuasaan negara-baik organ maupun fungsimenurut skema ajaran trias politica. Initinya adalah, memformat kekuasaan negara yang demokratis tidak absolut, dan dapat dokontrol satu sama lainnya (check and balances). (Arief Budiman, 1966 : 35-36)

Memang, tidak ada satu negara pun yang menganut mutlak skema asli trias politica itu. Namun demikian, core spirit ajaran tersebut (berupa kekuasaan negara yang demokratis, tidak absolut, dan dapat dikontrol), tetap menjiwai setiap varian negara hukum modem. Dalam kerangka core spirit inilah, menjadi amat penting keberadaan kekuasaan yudisial yang mandiri, yang mampu mengontrol secara hukum setiap cabang kekuasaan yang ada.

Perbedaan antara kosep "rechtsstaat" dengan "rule of law" hakikatnya hanya menyangkut keberada-an peradilan administrasi negara. Pada kosep "rschtsstaaf, peradilan adminis-trasi negara dijadikan salah satu unsur utama yang berdiri sendiri terpisah dari peradilan umum, sedangkan pada konsep "rule of law" eksistensi peradilan yang demikian itu dianggap tidak perlu. Ini terkait dengan prinsip "equality before the law" dalam konsep "rule of law" di mana pejabat maupun warga biasa sederajat di depan hukum, dan oleh karena itu sama-sama tunduk pada badan peradilan umum.

Perbedaan karakteristik antara sistem hukum Eropa \{Continental dan Anglo Saxon, juga ikut mewarnai perbedaan soal eksistensi peradilan administrasi negara itu. Sistem hukum negara Anglo Saxon yang berwawasan common law, memiliki karakteristik yudicial. Sedangkan sistem hukum Eropa \{Continental yang berwawasan civil law atau modern roman law, memiliki karakteristik administratif. (Philipus M. Hadjon, 1972 : 2). Itulah sebabnya, bagi negaranegara yang menganut rechtsstaat, pembatasan dan Peng-awasan yudicial terhadap tindakan melawan hukum oleh pemerintah, perlu dilembagakan secara otonom lewat peradilan administrasi negara. (Philipus M. Hadjon, 1972 : 78)

\section{Negara Hukum Menurut UUD'45}

Sejalan dengan penegasan perkembangan konsep negara hukum yang sudah tidak dipersoalkan lagi dari 
sumber istilahnya, Friedman mengemukakan, bahwa rechtstaat adalah pembatasan kekuasaan negara oleh hukum, dan rechtstaat adalah identik dengan the rule of law. (W. Friedman, 1960 : 456) Dalam Pembukaan dan Batang Tubuh UUD'45, eksplisit maupun implisit dimuat pengakuan dan perlindungan hak asasi manusia di semua bidang: Politik, Hukum, Sosial, Ekonomi, Kultural, dan Pendidikan. Bahkan dalam Pasal 28-A sampai 28-J telah dimuat 27 ketentuan Hak Asasi Manusia dalam UUD'45 pasca Amandemen.

Konsekuensi sebagai negara hukum, maka Indonesia harus memegang teguh tiga prinsip dasar: (1). Supremasi hukum (supremacy of law), (2). kesetaraan di depan hukum (equality before the law), (3). Penegakan hukum dengan cara-cara proses hukum yang adil (due proces of law). Tobias dan Petersen seperti dikutip Reksodiputro mengatakan bahwa due process of law merupakan "constitutional a guaranty that no person will be deprived of life, liberty or property for reasons that are arbitrary .. protects the citizen againts arbitrary actions of government".
Konsep Negara modem, identik dengan negara hukum yang demokratis. (Arief Budiman, 1966 : 34) Di situ, ada pemisahan atau pembagian kekuasaan negara baik organ maupun fungsi-menurut skema ajaran trias politica. Initinya adalah, memformat kekuasaan negara yang demokratis, tidak absolut, dan dapat dikontrol satu sama lainnya (check and balances). (Arief Budiman, 1966, him. 3536) Memang, tidak ada satu negara pun yang menganut mutlak skema asli trias political itu. Namun demikian, core spirit ajaran tersebut (berupa kekuasaan negara yang demokratis, tidak absolut, dan dapat dokontrol), tetap menjiwai setiap varian negara hukum modem. Dalam kerangka core spirit inilah, menjadi amat penting keberadaan kekuasaan yudisial yang mandiri, yang mampu mengontrol secara hukum setiap cabang kekuasaan yang ada.

\section{Kedudukan Presiden dan Mahkamah Konstitusi Indonesia}

\subsection{Lingkup Kekuasaan Presiden RI}

Pasal 4 amandemen UUD 1945 menyatakan: (1) Presiden Republik Indonesia memegang kekuasaan 
PERSPEKTIF Volume X No.3 Tahun 2005 Edisi Juli

pemerintahan menurut UndangUndang Dasar; (2) Dalam melakukan kewajibannya Presiden dibantu oleh satu orang Wakil Presiden. Presiden dan Wakil Presiden memegang jabatan selama lima tahun, dan sesudahnya dapat dipilih kembali dalam jabatan yang sama, hanya untuk satu kali masa jabatan. (Pasal 5, Pasal 7 Amandemen UUD 1945) Wewenang dan Hak Presiden:

a. Berhak mengajukan rancangan undang-undang kepada Dewan Perwakilan Rakyat [Pasal 5 ayat (1)Amandemen].

b. Dengan persetujuan Dewan Perwakilan Rakyat menyatakan perang, membuat perdamaian dan perjanjian dengan negara lain [Pasal 11 ayat, (1)]

c. Membentuk suatu dewan pertimbangan yang bertugas memberikan nasihat dan pertimbangan kepada Presiden, yang selanjutnya diatur dalam undangundang (Pasal 16).

d. Dalam hal mengangkat duta, Presiden memperhatikan pertimbangan Dewan Perwakilan Rakyat. Presiden menerima penempatan duta negara lain dengan menperhatikan pertimbangan Dewan Perwakilan Rakyat (Pasal 13).

e. Memberi grasi dan rehabilitasi dengan memperhatikan pertimbangan Mahkamah Agung;

f. Memberi amnesti dan abolisi dengan memperhatikan pertimbangan Dewan Perwakilan Rakyat; 45

g. Memberi gelar, tanda jasa, dan lainlain tanda kehormatan yang diatur dengan undang-undang. 46

h. Presiden dalam membuat perjanjian intemasional lainnya yang menimbulkan akibat yang luas dan mendasar bagi ke-hidupan rakyat yang terkait dengan beban keuangan negara, dan/atau mengharuskan per-ubahan atau pembentukan undang-undang haras dengan persetujuan Dewan Perwakilan Rakyat [(Pasal 11 ayat (1)].

i. Ketentuan lebih lanjut tentang perjanjian intemasional diatur dengan undang-undang [Pasal 11 ayat (2)].

Berdasarkan amandemen UUD 1945 di atas, pada dasamya Presiden RI memiliki 5 
(lima) lingkup kekuasaann pokok, yaitu kekuasaan : eksekutif, legislatif, diplomatik, yudikatif, dan kontraktual dengan Negara lain.

Persoalannya, kepada siapa atau lembaga manakah Presiden mempertanggung jawabkan pelaksanaan kelima kekuasaan tersebut? Sebagai konsekuensi logis dan dianutnya sistem presidensial atau sistem pemilihan langsung Presiden dan Wakil Presiden oleh rakyat berdasarkan Pasal 6A amandemen ketiga UUD 1945, maka secara politis Presiden bertanggung jawab kepada Rakyat atau Pemilihnya. Namun, bagaimanakah bentuk pertanggungjawaban tersebut ? Ternyata amandemen UUD 1945 tidak mengaturnya secara tegas, kecuali menyangkut pelanggaran hukum sebagaimana dimaksud Pasal 7A, Pasal 7 B dan Pasal 24C ayat (2) amandemen UUD 1945:

Persoalannya, kepada siapa atau lembaga manakah Presiden mempertanggung jawabkan pelaksanaan kelima kekuasaan tersebut? Sebagai konsekuensi logis dan dianutnya sistem presidensial atau sistem pemilihan langsung Presiden dan Wakil Presiden oleh rakyat berdasar- kan Pasal 6A amandemen ketiga UUD 1945, maka secara politis Presiden bertanggungjkawab kepada Rakyat atau Pemilihnya. Namun, bagaimanakah bentuk pertanggungjawaban tersebut ? Ternyata amandemen UUD 1945 tidak mengatumya secara tegas, kecuali menyangkut pelanggaran hukum sebagaimana dimaksud Pasal 7A, Pasal 7 B dan Pasal 24C ayat (2) amandemen UUD 1945:

\section{Pasal 7A}

Presiden dan/atau Wakil Presiden dapat diberhentikan dalam masa jabatannya oleh Majelis Permusyawaratan Rakyat atas usul Dewan Perwakilan Rakyat, baik apabila terbukti telah melakukan pelanggaran hukum berupa pengkhianatan terhadap negara, korupsi, penyuapan, tindak pidana berat lainnya, atau perbuatan tercela maupun apabila terbukti tidak lagi memenuhi syarat sebagai Presiden dan/atau Wakil Presiden.

\section{Pasal 7B}

1) Usul pemberhentian Presiden dan/atau Wakil Presiden dapat diajukan oleh Dewan Perwakilan Rakyat kepada Majelis Permusyawaratan Rakyat 
hanya dengan terlebih dahulu mengaju-kan permintaan kepada Mahkamah Konstitusi untuk memeriksa, mengadili, dan memutus pendapat Dewan Perwakilan Rakyat bahwa Presiden daNatau Wakil Presiden telah melakukan pelanggaran hukum berupa pengkhianatan terhadap negara, korupsi, penyuapan, tindak pidana berat lainnya, atau perbuatan tercela; danlatau pendapat bahwa Presiden dan/atau Wakil Presiden tidak lagi memenuhi syarat sebagai Presiden dan/atau Wakil Presiden.

2) Pendapat Dewan Perwakilan Rakyat bahwa Presiden dan atau Wakil Presiden telah melakukan pelanggaran hukum tersebut ataupun telah tidak lagi memenuhi syarat sebagai Presiden daNatau Wakil Presiden adalah dalam rangka pelaksanaan fungsi pengawasan Dewan Perwakilan Rakyat.

3) Pengajuan permintaan Dewan Perwakilan Rakyat kepada Mahkamah Konstitusi hanya dapat dilakukan dengan dukungan sekurang-kurangnya 2/3 dari jumlah anggota Dewan Perwakilan Rakyat yang hadir dalam sidang paripurna yang dihadiri oleh sekurangkurangnya 2/3 dari jumlah anggota Dewan Perwakilan Rakyat.

4) Mahkamah Konstitusi wajib memeriksa, mengadili, dan memutus dengan seadil-adilnya terhadap pendapat Dewan Perwakilan Rakyat tersebut paling lama sembila

\section{Pasal 7A}

Presiden dan/atau Wakil Presiden dapat diberhentikan dalam masa jabatannya oleh Majelis Permusyawaratan Rakyat atas usul Dewan Perwakilan Rakyat, baik apabila terbukti telah melakukan pelanggaran hukum berupa pengkhianatan terhadap negara, korupsi, penyuapan, tindak pidana berat lainnya, atau perbuatan tercela maupun apabila terbukti tidak lagi memenuhi syarat sebagai Presiden dan/atau Wakil Presiden.

\section{Pasal 7B}

1) Usul pemberhentian Presiden dan/atau Wakil Presiden dapat diajukan oleh Dewan Perwakilan Rakyat kepada Majelis Permusyawaratan Rakyat hanya dengan terlebih dahulu meng-ajukan 
permintaan kepada Mahkamah

Konstitusi untuk memeriksa, mengadili, dan memutus pendapat Dewan Perwakilan Rakyat bahwa Presiden daNatau Wakil Presiden telah melakukan pelanggaran hukum berupa pengkhianatan terhadap negara, korupsi, penyuapan, tindak pidana berat lainnya, atau perbuatan tercela; danlatau pendapat bahwa Presiden dan/atau Wakil Presiden tidak lagi memenuhi syarat sebagai Presiden dan/atau Wakil Presiden.

2) Pendapat Dewan Perwakilan Rakyat bahwa Presiden dan atau Wakil Presiden telah melakukan pelanggar-an hukum tersebut ataupun telah tidak lagi memenuhi syarat sebagai Presiden daNatau Wakil Presiden adalah dalam rangka pelaksanaan fiingsi pengawasan Dewan Perwakilan Rakyat.

3) Pengajuan permintaan Dewan Perwakilan Rakyat kepada Mahkamah Konstitusi hanya dapat dilakukan dengan dukungan sekurang-kurangnya 2/3 dari jumlah anggota Dewan Per-wakilan Rakyat yang hadir dalam sidang paripurna yang dihadiri oleh sekurang- kurangnya 2/3 dari jumlah anggota Dewan Per-wakilan Rakyat.

4) Mahkamah Konstitusi wajib memeriksa, mengadili, dan memutus dengan seadiladilnya terhadap pendapat Dewan Perwakilan Rakyat tersebut paling lama sembilan puluh had setelah permintaan Dewan Perwakilan Rakyat itu diterima oleh Mahkamah Konstitusi.

5) Apabila Mahkamah Konstitusi memutuskan bahwa Presiden dan/atau Wakil Presiden terbukti melakukan pelanggaran hukum berupa pengkhianatan terhadap negara, korupsi, penyuapan, tindak pidana berat lainnya, atau perbuatan tercela; dan/atau terbukti bahwa Presiden dan/atau Wakil Presiden tidak lagi memenuhi syarat sebagai Presiden dan/atau Wakil Presiden, Dewan Perwakilan Rakyat menyelenggarakan sidang paripurna untuk meneruskan usul pemberhentian Presiden dan/atau Wakil Presiden kepada Majelis Permusyawaratan Rakyat.

6) Majelis Permusyawaratan Rakyat wajib menyelenggarakan sidang untuk memutuskan usul Dewan Perwakilan Rakyat tersebut paling lambat tiga 
puluh hari sejak Majelis Permusyawaratan Rakyat menerima usul tersebut.

7) Keputusan Majelis Permusyawaratan Rakyat atas usul pemberhentian Presiden dan/atau Wakil Presiden harus diambil dalam rapat paripurna Majelis Permusyawaratan Rakyat yang dihadiri oleh sekurang-kurangnya 3/4 dari jumlah anggota dan disetujui oleh sekurangkurangnya 2/3 dari jumlah anggota yang hadir, setelah Presiden dan/atau Wakil Presiden diberi kesempatan menyampaikan penjelasan dalam rapat paripurna Majelis Permusyawaratan Rakyat.

Berdasarkan ketentuan diatas, jelaslah pertanggungjawaban Presiden Republik Indonesia, hanya dapat dimintakan oleh DPR dalam rangka melaksanakan kewenangan pengawasannya terhadap pelanggaran hukum yang dilakukan oleh Presiden, dengan tujuan untuk memberhentikan Presiden dan Wakil Presiden dari Jabatannya, melalui mekanisme sebagaimana dimaksud Pasal 7A dan Pasal 7B amandemen ketiga UUD 1945.

Akan tetapi, dengan konstelasi politik kepentingan dari berbagai partai politik yang dapat mendesakkan kepentingan mereka kepada Presiden untuk merekrut menteri-menteri dari partai mereka, dan/atau kepentingan Presdien sendiri untuk mengamankan kedudukan dan kebijakannya dari pengawasan DPR (yang terdiri dari berbagai Fraksi Partai Politik), maka menurut pendapat penulis peluang pelaksanaan pengawasan DPR untuk melaksanakan secara mumi dan konsekuen Pasal 7A dan Pasal 7B UUD 1945, juga sangat keal. Dengan kata lain, kedua pasal tersebut pada tataran normatif maupun empirisnya hanya bersifat nominal.

Oleh karena itu, ke depan layak ditingkatkan kedudukan Mahkamah Konstitusi menjadi Peradilan Tata Negara, yang tidak hanya menyelesaikan masalah judicial review, sengketa kewenangan antar lembaga Negara, Pembubaran Partai Politik, dan penyelesaian Sengketa Hasil Pemilihan Umum; tetapi juga hendaknya menyangkut penilaian terhadap kineqa Presiden dan Wakil Presiden.

\subsection{Kedudukan Mahkamah Konstitusi}

Kedudukan Mahkamah Konstitusi ditegaskan dalam Pasal 24 ayat (2) UUD'45, yakni sebagai salah satu 
pelaksana Kekuasaan Kehakiman di samping Mahkamah Agung 47. Membaca rumusan Pasal 24 ayat (2), sebagian pengamat menilai kedudukan Mahkamah Konstitusi yang dirumuskan dalam pasal tersebut, memberi kesan berada di bawah Mahkamah Agung. 48 Terlepas dari persoalan "keraguan membaca" tersebut, penulis hendak meng-konsentrasikan pembahasan pada bagaimana sesungguhnya kedudukam Mahkamah Konstitusi dalam UUD'45.

Jika membaca secara normatif Pasal 24 ayat (2), maka kedudukan Mahkamah Konstitusi sebagai pelaksana kekuasaan kehakiman berada sejajar dengan Mahkamah Agung. Cara penempatan Mahkamah Konstitusi secara paralel dengan Mahkamah Agung, jelas mengikuti tradisi civil law system yang melembagakan kekuasaan yudisial dalam dua tangan, yakni pada Mahkamah Agung dan Mahkamah Konstitusi (Constitutional Court).

Menurut hemat penulis, kedudukan Mahkamah Konstitusi tidak bisa diketahui secara tepat hanya dengan membaca Pasal 24 ayat (2) UUD'45. Pasal-pasal mengenai kelembagaan negara (Pasal 1 ayat (10) UUD'45), hak dan kewenangan Mahkamah Konstitusi
(Pasal 24-A ayat (1) UUD'45, Pasal 24-C ayat (1) UUD'45....), sesungguhnya secara implisit menetapkan kedudukan Mahkamah Konstitusi dalam struktur kenegaraan. Sebagai lembaga negara (Pasal 1 ayat (10) UUD'45) Mahkamah Konstitusi memiliki kedudukan yang sama dengan lembaga negara yang lain, termasuk MPR. Sesuai makna yang terkandung dalam Pasal I tersebut, bahwa kedaulatan berada di tangan rakyat dan dilaksanakan menurut UUD, maka bersamasama lembaga negara yang lain Mahkamah Konstitusi memiliki kedudukan yang sederajat dengan MPR. MPR bukan lagi lembaga tertinggi yang mengatasi lembaga-lembaga negara yang lain. Menyangkut kedudukan Mahkamah Konstitusi dalam bidang yudisial, penafsiran secara sistematis (dengan mengaitkan Pasal 24 ayat (2) dengan Pasal 24-A ayat (1) UUD'45 dan Pasal 24C ayat (1) UUD'45), justru memperlihatkan bahwa Mahkamah Konstitusi mengatasi bahkan memiliki kedudukan lebih tinggi dad Mahkamah Agung.

Kedudukan Mahkamah Konstitusi mengatasi Mahkamah Agung, karena Mahkamah Konstitusi berhak memutus sengketa kewenangan antar lembaga negara, sehingga membuka peluang 
Mahkamah Konstitusi mengadili Mahkamah Agung, khususnya dalam perkara judicial review. Kewenangan Mahkamah Konstitusi menguji materil (judicial review) UU (Pasal 24-C ayat (1) UUD'45), juga secara implisit memperlihatkan kedudukan Mahkamah Konstitusi lebih tinggi daripada Mahkamah Agung, karena Mahkamah Agung hanya memiliki kewenangan menguji materil peraturan di bawah UU (Pasal 24-A 40yat (1) UUD'45 amandemen ketiga).

\subsection{Tugas/Kewajiban Mahkamah Konstitusi}

Tugas MK menurut UUD'45 adalah sebagai berikut: (1). Memberi putusan atas pendapat DPR mengenai dugaan pelanggaran oleh Presiden dan/atau Wakil Presiden menurut UUD (Pasal 24 C: (ayat) 2). (2). Memeriksa, mengadili, dan memutus pendapat Dewan Perwakilan Rakyat bahwa Presiden dan/atau Wakil Presiden tidak lagi memenuhi syarat sebagai Presiden atau Wakil Presiden (Pasal 7 B (ayat) 2).

Dibandingkan dengan konsep ideal secara teoretis, tampak jelas bahwa tugas Mahkamah Konstitusi versi UUD'45 terbilang sangat terbatas. Tidak ditemukan rincian tugas yang mencerminkan Mahkamah Konstitusi sebagai pengawal dan penjaga konstitusi, seperti tugas menafsir konstitusi, mengontrol konstitusionalitas lembaga negara, mengontrol aktivitas parlemen agar tetap berada pada jalur konstitusi.

Di negara-negara lain seperti Jerman, Perancis, Maldova, Afrika Selatan, dan Thailand, Mahkamah Konstitusi memiliki tugas yang sangat vital mendasar, seperti interpretasi konstitusi (Jerman, Maldova, Afiika Selatan), menilai konstitusionalitas semua peraturan di luar konstitusi (Jerman, Maldova, Afiika Selatan, Thailand), memberi pendapat terhadap amandemen konstitusi (Maldova), mengadili pelanggaran hak dasar (Jerman), menentukan inkonstitusionalitas keputusan MA (Maldova), menjamin pelaksanaan referendum (Perancis), menilai konstitusionalitas tindakan parlemen (Afiika Selatan), dan lain sebagainya. Dalam konteks reformasi, tugas Mahkamah Konstitusi seharusnya dikaitkan dengan proses demokratisasi, transparansi dan akuntabilitas lembagalembaga negara, serta menjamin tegaknya konsbtusi. 
4.4. Wewenang Mahkamah Konstitusi a. Kewenangan Judicial Review

Dilihat dari latar sejarahnya, kewenangan judicial review sebenamya merupakan tindak lanjut dari kritikan terhadap Pasal 5 ayat (1) Tap MPR Nomor III/MPR/2000 tentang Sumber Hukum dan Tata Urutan Peraturan Perundang-undangan yang memberi kewenangan bagi MPR untuk menguji UU terhadap UUD dan Tap MPR 52. Kewenangan mi hanya dibatasi pada UU. Selain catatan yang telah kemukakan pada poin tentang kedudukan MK, penulis hendak menambahkan beberapa catatan tambahan tentang kewenangan judicial review.

Pertama, sulit dipahami mengapa kewenangan judicial review yang diberikan kepada MK hanya terbatas pada UU. Pemisahan kewenangan judicial review terhadap peraturan perundangan di luar konstitusi antara MA (untuk peraturan di bawah UU) dan MK (untuk UU), terkesan kurang didasarkan atas pendalaman konseptual mengenai konsepsi komprehensif hak uji itu sendiri. Dalam sistem pemisahan kekuasaan (formal and horizontal separation of power) yang mengutamakan mekanisme checks and balances yang telah dianut UUD'45 hasil amandemen, maka pemisahan antara materi UU dan materi di bawah UU tidak seharusnya dilakukan. Demi terjaminnya konstitusionalitas semua peraturan per-undangan, mestinya MK diberi ke-wenangan ganda, yakni selain judicial review terhadap semua peraturan di luar konstitusi termasuk produk-produk MPR, juga kewenangan legislation review terhadap semua rancangan peraturan, baik dalam bentuk RUU maupun rancangan peraturan lain yang setara maupun di bawahnya, bahkan terhadap materi amandemen UUD. Dengan kewenangan mi, beberapa manfaat dapat diraih sekaligus:

- Dimungkinkan terciptanya harmonisasi hukum baik menyangkut muatan maupun jiwanya.

- Mencegah terjadinya pertentangan substantif antara peraturan di bawah UU yang direview oleh MA dengan UU yang direview oleh MK.

- Dengan menyerahkan judicial review semua peraturan perundangan kepada MK, maka 
MA lebih dapat mengkosentrasikan did pada penanganan persoalan keadilan dan ketidakadilan bagi warga negara, sedangkan MK menjamin konstitusionalitas keseluruhan peraturan perundangan.

- Pengambilalihan kewenangan tersebut oleh MK, dapat mengurangi beban MA dalam menangani perkara-perkara konvensional.

Kedua, sulit pula dipahami mengapa hak judicial review MK bersifat pasif . Sebagai penjaga dan pengawal konstitusi, mestinya hak tersebut bersifat aktif sehingga MK memiliki kewenangan proaktif dan berperan mencari peraturan yang dianggap bertentangan dengan konstitusi.

\section{b. Menangani Sengketa Kewenangan Antar Lembaga Negara.}

Kewenangan MK mengadili dan memutus sengketa antar-lembaga negara, adalah lembaga negara yang diberikan (dicantumkan) kewenangannya dalam UUD'45, yakni MPR, DPR, Presiden, MA, BPK, Komisi Yudisial, dan Komisi Pemilihan Umum. Sengketa kewenangan antarlembaga di daerah yang menyangkut perundang-undangan di bawa UU menjadi kewenangan Mahkamah Agung. Sedangkan bila sengketa itu menyangkut keputusan administratif pejabat lembaga negara, maka termasuk yurisdiksi Peradilan Tata Usaha Negara.

Tampak bahwa kewenangan Mahkamah Konstitusi menangani sengketa antar lembaga negara, masih terbilang amat terbatas dan potensil menimbulkan masalah. Kewenangan MK Indonedia tidak menjangkau sengketa yang melibatkan lembaga di daerah dengan lembaga di pusat, sengketa antar lembaga di daerah, antara daerah dengan pusat, serta perselisihan antara daerah satu dengan daerah yang lain. Hal tersebut menjadi krusial untuk ditangani oleh MK, karena pelaksaan otonomi daerah saat ini memungkinkan terjadinya konflik tersebut di atas-yang secara langsung maupun tidak langsung dapat mengancam integrasi negara dan bangsa.

\section{c. Kewenangan Pembubaran Partai Politik}

Kewenangan MK mengadili dan memutuskan pembubaran Partai Politik, 
dalam pelaksanaannya tentu berpedoman pada UU No.....Sebuah Parpol dapat dibubarkan oleh MK, jika (1). Pengurus Parpol menggunakan partainya untuk melakukan kegiatan menganut, mengembangkan, dan menyebarkan ajaran atau paham komunisme/ marxisme-leninisme, (2). Dituntut berdasarkan UU No. 27 Tahun 1999 tentang perubahan KUHPidana yang berkaitan dengan kejahatan terhadap keamanan negara.

Mengenai pelanggaran lain yang dilakukan oleh sebuah Parpol, diperiksa oleh Peradilan Perkara Parpol, yaitu diselesaikan di Pengadilan Negeri sebagai putusan tingkat pertama dan terakhir, dan hanya dapat diajukan kasasi ke MA. Proses di Pengadilan Negeri paling lama 60 had, dan kasasi paling lama 30 hari. Pelanggaran Parpol yang dapat diajukan ke Peradilan Perkara Parpol di Pengadilan Negeri, adalah: (1). Melakukan kegiatan yang bertentangan dengan UUD'45 atau peraturan perundangan lainnya. (2). Melakukan kegiatan yang membahayakan keutuhan Negara Kesatuan RI. (3). Melakukan kegiatan yang bertentangan dengan kebijakan pemerintah negara dalam memelihara persahabatan dengan negara lain dalam rangka ikut memelihara ketertiban dan perdamaian dunia. Sanksi yang dapat dijatuhkan atas pelanggaran di atas, adalah sanksi administratif berupa pembekuan paling lama 1 tahun.

\section{d. Kewenangan Memutus Perselisihan Hasil Pemilu}

Mahkamah Konstitusi diberi kewenangan oleh UUD memutus perselisihan hasil pemilihan umum. Putusan hasil pemilihan umum oleh KPU adalah putusan tata usaha negara. Keputusan KPU tentang hasil pemilihan umum tidak dapat digugat di peradilan tata usaha negara, tetapi dapat digugat di peradilan Mahkamah Konstitusi. Secara teknis, ada beberapa masalah menyangkut kewenangan ini, yakni (1). Apakah sengketa Pemilu yang dimaksud meliputi hasil akhir secara nasional, ataukah juga lokal. (2). Batasan sengketa hasil Pemilu yang dapat diproses oleh Mahkamah Konstitusi, apakah termasuk sengketa yang terjadi di tingkat TPS.

Kehadiran Mahkamah Konstitusi dalam sistem ketatanegaraan Indonesia setelah amandemen UUD'45, sebetulnya membawa harapan baru dalam me- 
wujudkan check and balances, serta kehidupan demokrasi yang lebih memihak pada kepentingan publik dalam ketata-negaraan Indonesia. Namun demikian, terdapat pelbagai persoalan yang cukup mengganjal, baik pada kedudukan, kewenangan, maupun kewajiban Mahkamah Konstitusi yang justru dapat mereduksi manfaat dan fungsinya pokoknya dalam konteks ketatanegaraan dan konstitusi Indonesia. Pada bab VI karya ini akan diajukan gagasan altematif tentang kedudukan, tugas, dan wewenang Mahkamah Konstitusi yang compatible atau ekuivalen dengan tuntutan cita hukum dan gagasan normatif negara hukum Indonesia yang dituntut oleh konstitusi.

\section{Signifikansi MK dalam Konteks Negara Hukum}

Mengenai perlu tidaknya MK di Indonesia, tidak ada kesatuan pendapat. Meski banyak yang mendukung, namun ada pula yang memandang sebaliknya. Pemikiran seperti ini, misalnya diajukan oleh A.S.S. Tambunan. (A.S.S Tambunan, 2003) Ada dua argumentasi inti yang diajukan: (1). Meski Indonesia tergolong dalam jajaran Civil Law System, namun dengan keberadaan hukum adat yang dekat dengan Common Law, membuat sistem hukum Indonesia tidak mengenal asas "UU tidak dapat diganggu-gugat". (2). Sistem UUD 45 tidak hanya mengenal konstitusi tertulis tetapi juga mengenal konvensi. Dengan demikian, selain tidak mengenal asas "UU tidak dapat diganggugugat", tetapi UUD 45 tidak melarang hakim pengadilan biasa melakukan judicial review of legislation. (A.S.S Tambunan, 2003, him. 10)

Ada beberapa keberatan yang dapat diajukan terhadap argumentasi di atas. Pertama, gagasan tentang MK merupakan buah hasil amandemen ke-3 dari UUD 45 yang lebih condong pada pemikiran Trias Politico Montesquieu, yakni check and balances. UUD 45 hasil amandemen tidak mengikuti tradisi Eropa Klasik warisan Yunani yang menempatkan lembaga legislasi dan produkproduknya sebagai poros negara republik.

Kedua, faktual negara-negara Eropa Continental dengan sistem civil law, sudah mengadopsi perkembangan baru abad ke-18, di mana kedudukan lembaga yudikatif menjadi seimbang dengan kedudukan lembaga legislatif dan eksekutif. Bahkan dalam beberapa hal, 
kedudukan yudikatif lebih superior dad yang lain. Peranan yudikatif menjadi sarana untuk mengontrol lembagalembaga yang lain, dalam bentuk: (1). Mengkaji apakah UU hasil legislatif sesuai atau tidak dengan konstitusi (judicial review of the constitutionality of legislation) 57, (2). Badan-badan peradilan berhak mengawasi dan mengontrol kegiatan pemerintahan yang dilakukan oleh badan eksekutif apakah sesuai dengan landasan hukurnnya, (3).

Pada beberapa negara, lembaga yudikatif bertindak sebagai arbiter (penengah) apabila terjadi konflik yuridis antara lembaga-lembaga negara mengenai wewenang fungsional masingmasing. Perundang-undangan mengenai sistem peradilan di Indonesia, dan juga UUD hasil amandemen sudah berada dalam jalur yang baru tersebut

Ketiga, gagasan judicial review of legislation yang bermula di daratan Eropa Kontinental, sebenamya merupakan suatu usaha untuk mengimbangi superioritas kekuasaan legislatif. Hadirnya mahakamh konstitusi ataupun badan konstitusi di negara-negara tersebut, bukan saja bermakna meninggalkan pemikiran klasik Eropa warisan Yunani, tetapi juga asas "UU tidak dapat diganggu gugat" hanya berlaku bagi peradilan biasa, bukan bagi mahkamah konstitusi.

Keempat, kondisi perundangundangan di Indonesia yang mayoritas tidak mutu, menghendaki adanya lembaga khusus yang dapat melakukan 'koreksi' terhadap mated perundang-undangan dimaksud. Asas-asas klasik seperti UU buatan legislatif tidak dapat diganggugugat, la bouche de la lots (hakim merupakan mulut $\mathrm{UU}$ ), tugas seorang hakim hanya menerapkan UU yang dibuat oleh lembaga legislatif, dan qui les juges suivent la lettre de la lois (para hakim harus menuruti secara harfiah apa kata UU). (G.J Wiarda, Die Typen van Rechtsvinding, Zwolle, 1980, him. 11) tidak bisa diandalkan untuk mengelola Indonesia yang sedang membangun.

Harus dikatakan di sini bahwa kuatnya cara berpikir legalisme selama ini, menjadi salah satu penyebab utama kelumpuhan hukum di negeri ini. Ketakberdayaan hukum menjerat beragam pelanggaran dalam kampanye Pilpres yang baru lalu, merupakan bukti mutakhir penyakit legalisme di tanah negeri. Berbagai praktik kecurangan 
dilakukan begitu telanjang, tapi semua itu tidak bisa ditindak hanya lantaran redaksi atau teks peraturan tidak menyebut secara eksplisit unsur-unsur dari penyimpangan yang terjadi. Alhasil, acara "temu kader dan simpatisan" atau penyerahan "sumbangan presiden" yang begitu giat dilakukan para Capres tidak bisa ditindak sebagai pelanggaran karena teks dan redaksi peraturan tidak menyebut kegiatan seperti itu sebagai kegiatan kampanye.

Kita menyaksikan di situ, aparat seolah menjadi robot, begitu mekanistis dan hitam-putih melihat persoalan. Teks dan redaksi aturan seolah begitu digdaya membelenggu kearifan dan akal sehat. Nyaris tidak ada keberanian melakukan sesuatu di luar teks dan redaksional aturan.

Inti dari kemacetan itu adalah, kecenderungan menjadikan aturan sebagai tujuan dalam dirinya sendiri. Kejujuran dan kearifan dalam menjalankan hukum, terdorong ke belakang. Akibatnya, kepekaan, empati, serta dedikasi menghadirkan keadilan dan kebenaran menjadi kian redup dan sayupsayup di pojok yang paling jauh.

Apa sebab? Sekali lagi, penyakit legalisme. Legalisme, menyebabkan aturan jadi "berhala, kebidupan jadi kaku, kenyataan yang kaya nuansa dilihat pakai "kacamata kuda", kebenaran dan keadilan hanya menjadi persoalan legal-tidak legal, kearifan dan akal sehat terdorong ke belakang. Itulah legalisme. Sebuah semangat yang coute que coute, mentuhan peraturan. Aliran ini mematrikan aturan sebagai tempat satu satunya bagi hakim dalam mengadili. Ham menjadi corong wet. Hakim hanya boleh menerapkan UU secara mekanis!

Maka jarang pula kita temukan aparat hukum yang mampu dan berani melakukan terobosan menemukan keadilan dan kebenaran lewat penafsiran hukum yang kreatif. Prinsip epikeia Aristoteles, ataupun equitynya Plato yang fungsinya menjembatani gap antara kepastian dan keadilan, kian sima dari aktivitas penegakan hukum.

Untuk diketahui, doktrin-doktrin hukum seperti legalisme, positivisme hukum atau Ideenjurisprudenz, dan rechtsdogmatiek atau analytical jurisprudence hanya merupakan merupakan bagian kecil dad sekian tonggak pemikiran hukum dalam peradaban manusia. Di samping doktrin doktrin tersebut, orang juga masih berbicara tentang nomos dan keadilan 
(zaman klasik), Fret Rechtslehre dan Historism (awal abad ke-20), Interaessenjurisprudenz, Sociological Jurisprudence, dan Realistic Jurisprudence (abad ke 20), serta Hukum Responsifdaa Hukum Progresif(era kontemporer).

Rechtsdogmatiek yang masih dianut kuat dalam dunia hukum di Indonesia, merupakan salah satu tipe saja dari sekian ragam pemikiran tentang hukum. la merupakan ciri pemikiran tipikal abad ke-19 di mana pengagungan otonomi individu, rasionalisme-dualistis, dan nation state sedang berkibar. Bahwa 'fosil' abad ke-19 itu masih kokoh-utuh diamini komunitas hukum dan akademikus di negeri yang sedang membangun dan sedang menghadapi keadaan serba darurat seperti Indonesia, memang diarasakan cukup mengganggu.

Berbeda dengan kelompok doktrin yang positif-legalistis, maka Frei Rechtslehre, Interessenjurisprudenz, Hukum Responsif, ataupun Hukum Progresif tergolong pemikiran hukum yang lebih teleologis dan kontekstual seperti. Bagi aliran-aliran ini, hukum itu bukan merupakan institusi yang lepas dari kepentingan manusia. Mutu hukum, ditentukan oleh kemampuannya untuk mengabdi pada kesejahteraan manusia.

Aliran-aliran tersebut, memang mengandalkan pemeriksaan yang cermat dan serius atas kepentingan-kepentingan yang dipertaruhkan dalam suatu kasus konkret-berikut konteksnya yang relevan. Kemudian dengan menimbang bobot kepentingan yang dianggap lebih utama, diambillah keputusan yang mendukung kepentingan yang lebih utama tersebut.

Sekalian aliran tersebut tegastegas menolak pertimbangan yuridis yang legalistik yang dilakukan secara pasang jarak dan in abstract, la tidak memulai pemeriksaan dad bangunan peraturan secara hitam-putih, melainkan dad konteks dan kasus khusus di luar narasi tekstual aturan itu sendiri. Sebab keadilan tidak bisa secara langsung ditemukan lewat proses logis-formal. Keadilan justru diperoleh lewat intuisi. Karenanya, argumen-argumen logis-formal "dicari" sesudah keadilan ditemukan untuk membingkai secara yuridis-formal keputusan yang diyakini adil tersebut.

Frei Rechtslehre, Interessenjurisprudenz, Hukum Responsif, ataupun Hukum Progresif, tidak sekali-kali menafikan peraturan. Meski begitu, aliran- 
aliran tersebut tidak seperti legalisme dan rechtsdogmatiek yang mernatok peraturan doktrin sebagai harga mati. Tidak juga seperti analytical jurisprudence yang hanya berkutat pada proses logisformal. Baik Frei Rechtslehre maupun Interessenjurisprudenz, Hukum Responsif, dan Hukum Progresif, berusaha menolak keadaan status quo manakala keadaan tersebut menimbulkan dekadensi, suasana korup, dan semangat merugikan kepentingan manusia. Dalam aliran-aliran itu, melekat semangat "perlawanan" dan "pemberontakan" untuk mengakhiri kelumpuhan hukum melalui aksi kreatif dan inovatif para pelaku hukum. Para pelaku hukum dapat melakukan per-ubahan dengan melakukan pemaknaan yang kreatif terhadap peraturan yang ada, tanpa harus menunggu perubahan pe-aturan (changing the law). Peraturan yang buruk, tidak harus menjadi penghalang bagi para pelaku hukum yang progresif untuk menghadirkan keadilan untuk rakyat dan pencari keadilan, karena mereka dapat melakukan interpretasi secara baru setiap kali terhadap suatu peraturan.

Kelompok teori yang progresif itu lebih menekankan kaidah (ius, recht, norm) dari pada teks aturan (lex, wet, rule) dalam membaca hukum. Kaidah itu adalah makna spiritual, roh. Sedangkan teks aturan adalah penerjemahan ke dalam kata-kata dan kalimat. Hukum mempunyai tujuan. Itulah yang haras direfleksi lebih lanjut, Terkadang roh dan tujuan itu, cenderung hilang di tengah rimba kalimat kalimat, pasal-pasal.

Logika peraturan, hanya sal ah satu saja, dan yang paling sederhana dalam membaca hukum. Masih ada logika lain yang perlu dimasukkan manakala diinginkan untuk membaca hukum dengan lebih baik, yaitu logika kepatutan sosial (social reasonableness) dan logika keadilan. Logika ini tidak bisa segera ditemukan dengan membaca peraturan, tetapi dibutuhkan suatu perenungan dan pemaknaan lebih dalam terhadap apa yang dibaca itu.

Membaca kaidah, bukan peraturan, adalah pedoman yang amat baik dalam penegakan hukum. Membaca kaidah adalah menyelam ke dalam roh dan tujuan hukum. Ini membutuhkan perenungan. Meski kalimat-kalimat bitamputih, yang namanya peraturan, sudah dibaca, kita tetap merenungkan tentang apa makna lebih dalam kalimat-kalimat itu. 
Di mana letak rohnya, keadilannya. Cara membaca yang mendalam seperti ini, jelas tidak bertolak dari teks tapi dari konteks. Kelompok aliran yang progresif, berangkat dari titik ini.

Semangat progresif itu sematamata oleh karena Frei Rechtslehre, Interessenjurisprudenz, Hukum Responsif, dan Hukum Progresif, melihat hukum bukan sebagai tujuan pada dirinya sendiri, melainkan untuk tujuan yang berada di luar dirinya. Oleh karena itu, kelompok aliran yang progresif itu meninggalkan tradisi analitical jurisprudence atau rechtsdogmatiek yang hanya melihat ke dalam hukum dan menyibukkan diri dengan membicarakan dan melakukan analisis ke dalam 59, sementara dunia di luar, seperti manusia, masyarakat, kesejahteraan, ditepis ke luar 60. Meminjam istilah Nonet-Selznick, kelompok aliran yang progresif tersebut memiliki prioritas "the souvereignity of purposei 61. Lebih lanjut Nonet dan Selznick mengatakan,

"...Thus a distinctive feature of responsive law is the search of implicit values inrules and policies ...a more flexible interpretation that sees rules as bound to specific problems and contexts, and undertakes to identify

the values at stake in

$$
\text { procedural protection ". }
$$

Apa yang dipikirkan oleh Nonet dan Selznick sebetulnya ingin mengritik model analitical jurisprudence atau rechtsdogmatiek yang hanya berkutat di dalam sistem aturan hukum positif 63 , model yang mereka sebut dengan tipe hukum otonom. Hukum responsif, sebaliknya, dipandang sebagai fasilitator respons atau sarana tanggapan terhadap kebutuhan dan aspirasi sosial. Itulah sebabnya, hukum responsif merupakan program dari sociological jurisprudence dan realist jurisprudence 64 . Dua aliran tersebut, memang dikerangkakan sebagai sebuah seruan untuk kajian hukum yang lebih empirik-perluasan pengetahuan hukum, dan peran kebijakan dalam putusan hukum 65. Dalam sociological jurisprudence dan legal realism, pemahaman orang mengenai hukum melampaui peraturan atau teksteks dokumen dan "looking towards" proses, hasil, akibat, dan manfaat dari hukum itu (Lib dalam Theo Huijbers, 1982 :180)

Perhatian pada tujuan dan akibat dari hukum tersebut, memperlihatkan 
suatu cara pandang etis yang dalam etika disebut etika teleologis. Cara berpikir teleologis ini bukan tidak mengacuhkan hukum. Tapi, itu bukan ukuran terakhir. Yang lebih penting ialah tujuan dan akibat. Sebab itu, pertanyaan sentral dalam etika teleologis, ialah: "apakah suatu tindakan itu bertolak dari tujuan yang baik? Dan apakah tindakan yang tujuannya baik itu, juga berakibat baik? Cara berpikir teleologis, oleh karenanya tidak berpikir menurut kategori "benar" dan "salah", tapi menurut kategori "baik" dan "jahat". Betapapun betapapun "benar"-nya, kalau dilakukan dengan tujuan jahat, apalagi berakibat buruk, maka ia "jahat".

Cara berpikir teleologis berseberangan dengan cara berpikir deontologis. Cara berpikir yang disebut terakhir ini menyerupai logika analitical jurisprudence atau rechtsdogmatiek di bidang hukum. Deontologis adalah cara berpikir etis yang mendasarkan diri pada hukum, prinsip, atau norma obyektif yang dianggap harus berlaku dalam situasi dan kondisi apapun. Menaati prinsip, berarti benar. Melanggar prinsip, berara salah. Tidak ada kompromi. Etika yang deontologis, karenanya berbicara tentang apa yang benar dan apa yang salah.

Cara berpikir seperti ini memang ada manfaatnya. la memberi pegangan etis dengan tegas dan jelas. Orang tidak perlu bingung tentang apa yang benar dan apa yang salah, asal saja hukumnya jelas. Tapi justru dalam hal yang terakhir inilah kita menghadapi kesulitan. Kehidupan manusia itu begitu kompleks dan begitu dinamisnya, sehingga hampir mustahil mempunyai hukum yang jelas bagi setiap kemungkinan.

Mungkin akan sedikit terbantu, seandahiya peraturan itu diperinci lagi sedemikian rupa, sehingga ia dapat menjawab semua kemungkinan. Solusi ini memang logis, tapi hampir mustahil terjadi. Selain hukum berubah menjadi kasuistri-satu daftar panjang tentang apa yang boleh dan apa yang dilarang, tetapi juga daftar seperti itu tidak mungkin dapat dikerjakan dengan lengkap dan sempuma. Ekses lain adalah, hukum dapat menjadi legalisme yang beku dan kaku. Hukum, tidak lagi melayani manusia, tapi sebaliknya manusia melayani hukum.

Mengenai signifikansi MK dalam konteks negara hukum, sebenamya 
berkaitan dengan prinsip-prinsip pokok negara hukum yang demokratis, yakni: supremasi hukum, jaminan hak-hak asasi manusia, check and balances dalam negara, dan rechterlijke controle. Bagaimana signifikansi MK dalam meneguhkan norma-norma dasar negara hukum?

Perteori, Mahkamah Konstitusi dibentuk agar berfungsi sebagai lembaga penafsir kons-titusi, menyelesaikan sengketa konstitusi, melakukan proses judicialization of politics, melakukan judicial review terhadap semua perundangundangan di luar konstitusi 67 dan sebagainya. Logisnya, MK dapat menangani sekalian itu.

\section{PENUTUP}

Mencermati pertanggung jawaban Presdien Menurut Amandemen UUD 1945 dapat disimpulkan, bahwa :

Pertanggungjawaban Presiden Republik Indonesia, hanya dapat dimintakan oleh DPR dalam rangka melaksanakan kewenangan pengawasannya terhadap pelanggaran hukum yang dilakukan oleh Presiden, dengan tujuan untuk memberhentikan Presiden dan Wakil Presiden dari jabatannya, melalui mekanisme sebagaimana dimaksud Pasal 7A dan Pasal 7B amandemen ketiga UUD 1945.

Akan tetapi, dengan konstelasi politik kepentingan dari berbagai partai politik yang dapat mendesakkan kepentingan mereka kepada Presiden untuk merekrut menteri-menteri dari partai mereka, dan/atau kepentingan Presdien sendiri untuk mengamankan kedudukan dan kebijakannya dari pengawasan DPR (yang terdiri dari berbagai Fraksi Partai Politik), maka menurut pendapat penulis peluang pelaksanaan pengawasan DPR untuk melaksanakan secara mumi dan konsekuen Pasal 7A dan Pasal 7B UUD 1945, juga sangat kecil. Dengan kata lain, kedua pasal tersebut pada tataran normatif maupun empirisnya hanya bersifat nominal.

Oleh karena itu, ke depan layak ditingkatkan kedudukan Mahkamah Konstitusi menjadi Peradilan Tata Negara, yang tidak hanya menyelesaikan masalah judicial review, sengketa kewenangan antar lembaga Negara, Pembubaran Partai Politik, dan penyelesaian Sengketa Hasil Pemilihan Umum; tetapi juga menyangkut penilaian terhadap kinerja Presiden dan Wakil Presiden, sebagai wujud pertanggung jawaban kongkretnya 
terhadap penyelenggaraan urusan pemerintahan Negara secara yuridis konstitusional.

\section{DAFTAR PUSTAKA}

A. Haid Atamimi, Peranan Keputusan Presiden RI dala $P$ e $n$ y e l e ng g a $r$ a a $n$ Pemerintahan Negara, Disertai Universitas Indonesia, 1990

A. S. S Tambunan, "Apakah Negara RI dibawah Naungan ULTD 19431Vlemerlukan Mahkamah Konstitusi? , Orasi IImiah pada Wisuda Sarjana Hukum STHM, 2 Oktober 2003

Brian Thompson, Textbook on Constitusional and administrative Law, London: Blackstone Press Ltd. 1997

CJ Friedrich, man and His Government, New York: McGraw-Hill, 1963

Charles H. Mcllwain, Constitutionalsm: ancient and modern, Ithaca, New York: Carnell University Press, 1996

C.F Strong, Moderen Political Constitutions. London, ELM and Singwick \& Jakson Limited, 1966

Ivo.D.Duchacek, "Constitution IConstitutionalism", dalam Bogdanor, Vernan (ed) Blackwell's Encyclopedia of political Science, Oxford:
Blackwells, 1987

Ismail Suny, Konstitusi 1945 dan Hak Asasi manusia" dalam Hak Rakyat atas Pembangunan, 40 Tahun Deklarasi Umum Hak Asasi Manusia, Jakarta: YLBHI, 1989

Ismail Suny, Pergeseran Kekuasaan Eksekutif, Aksara Baru, Jakarta, 107

Jimly Ass'hitTfiqie, Cita Negara Hulcum Kontemporer, Orasi IImiah pada Wisuda Sarjana Hukum Universitas Sriwijaya Palembang, 23 Maret 2004

J. Bryce, Studies in History and Jurisprudence, Vol. 1 Oxford: Clarendon Press, 1901

Jimly Asshiddiqie, Konsolidadi Aiaskah UUD 45 setelah perubahan Keempat, Jakarta: Pusat Studi Hukum Tata Negara FH - UL 2002

Konsep Kant tersebut dikenal dengan sebutan" Nachtwkerstaat" atau Nachtwachterstaat" (lihat. Azhary, Negara Hukum Indonesia, Jakarta: UIPRESS,.1995)

M. Mahfud MD, Demokrasi dan Konstitusii di Indonesia, Jakarta: Rineka Cipa, 2000

Philips 0. Hood \& Jackson, Constitutional and Administrasi Law, 7 th ed, London: Sweet and Maxwell, 1987

Philipus M. Hadjon, Perlindungan Hukum Bagi Rakyat di Indonesia, Sebuah Studi Tentang Prinsip-Prinsipnya, 
Penerapannya Oleh Oleh Pengadilan Dalam Lingkungan Peradilan Umum Dan Pembentukan Pradilan Adminisrasi Negara, Binallmu, Surabaya, 1972
W. Friedmanj 1960, Legal Theory, London, Stem \& Sou Liited, hal. 456. 